\title{
СОЦИОЛОТИЧЕСКИЕ HАУКИ
}

\author{
ВОСТОК ЗАПАД НОВОЕ ИЗМЕРЕНИЕ: ЕДИНАЯ ЦЕНТРАЛЬНАЯ АЗИЯ \\ СВЯЗАЮУЩЕЕ ЗВЕНО
}

\author{
Жураев Сайфиддин Ахматович \\ доктор политических наук, профессор \\ Ташкентского государственного университета Востоковедения
}

DOI: 10.31618/ESU.2413-9335.2020.6.76.935

\section{АННОТАЦИЯ}

В статье рассматриваются внешняя политика и ее особенности в Узбекистане. Автором проанализирован история развития и реформы внешней политики Узбекистана с зарубежными странами, а также изучены концептуальные положения в отношении взаимодействия со странами ЦА.

Ключевые слова: восток, запад, реформа, регион, политика

Новый Узбекистан. В стране претворяются в жизнь масштабные реформы во всех сферах. Происходят серьезные преобразования в экономике и социальной политике. Все это обусловлено потребностями общества и волей Президента Шавката Мирзиёева вывести Узбекистан на совершенно иной этап исторического развития.

Обновились и приоритеты республики во внешней политике. Акцент сделан на активизацию взаимоотношений с соседними странами. Проведение эффективной региональной дипломатии, создание благоприятной политической атмосферы в Центральной Азии, выстраивание конструктивного диалога и взаимовыгодных партнерских связей с государствами региона, укрепление безопасности и стабильности - таковы важные направления внешнеполитической деятельности Узбекистана.

Концептуальные положения в отношении взаимодействия со странами ЦА Президент Шавкат Мирзиёев подробно изложил в сентябре 2017-го на 72-й сессии Генеральной ассамблеи ООН в НьюЙорке. А на Самаркандской конференции «Центральная Азия: одно прошлое и общее будущее, сотрудничество ради устойчивого развития и взаимного процветания», которая прошла 10 ноября того же года, лидер республики выдвинул новую философию региональных отношений на современном этапе.

Центральная Азия обладает мощным культурно-цивилизационным наследием, огромным ресурсным потенциалом, уникальными транспортно-коммуникационными

возможностями. Регион сохраняет свое исключительное геополитическое значение. Происходящие здесь процессы оказывают ощутимое влияние на состояние безопасности всего континента. Таким образом, разделить культурно-историческое наследие региона просто невозможно. Общие история и религия, единые водные артерии и транспортные коридоры - это достояние всех народов ЦА. Именно поэтому главной целью обозначено снижение конфликтного потенциала в регионе, укрепление доверия, налаживание взаимовыгодных связей.
Однако взаимодействие пока сдерживается целым комплексом неурегулированных вопросов от делимитации и демаркации границ до справедливого и рационального распределения водных ресурсов. По данным ПРООН, ущерб от отсутствия должного решения вопросов рационального распределения водных ресурсов в регионе оценивается в 1,7 млрд долларов в год. В связи с этим необходимо принять конвенции об использовании водных ресурсов рек Амударьи и Сырдарьи, предложенные ООН всем странам Центральной Азии. Главный вызов, стоящий перед ЦА, - распространение экстремистских, далеких от истинно мусульманских ценностей идей.

В последние годы начали появляться все новые возможности для углубления сотрудничества. Растет интенсивность политических контактов.

В 2017 году Президент Узбекистана провел 16 встреч на высшем уровне, 18 телефонных разговоров, были три государственных и два рабочих визита. Особую значимость здесь имеет организация регулярных консультативных встреч глав государств Центральной Азии, которые позволяют «сверять часы» по самым актуальным вопросам, определять дальнейшие шаги по укреплению и расширению сотрудничества, устанавливать модели взаимодействия, направленные на обеспечение безопасности и мира в регионе.

В 2018-м состоялись обмены визитами на высшем уровне со всеми странами ЦА. По итогам первого государственного визита Президента Узбекистана в Таджикистан подписаны документы стратегического характера: Совместное заявление об укреплении дружбы и добрососедства и Договор об отдельных участках узбекско-таджикской Государственной границы. В ходе официального визита Президента Туркменистана в Узбекистан стороны подтвердили готовность задействовать в полном объеме транзитный потенциал двух стран для увеличения объемов перевозки грузов в страны Европы, Ближнего Востока и Азии.

Вектор дипломатических отношений нашей республики сейчас взят на устранение источников недоверия, конфликтов, межнациональных споров. Открываются границы с ближайшими странами. 
Это показывает, что политическая ситуация в регионе принципиально изменилась в плане взаимного доверия. Главным внешнеполитическим событием, безусловно, можно считать запуск консультативных встреч глав государств Центральной Азии. Первая состоялась в Астане 15 марта 2018 года и ознаменовала переход на новый этап в региональном сотрудничестве. В ходе встречи определены базовые приоритеты и намечены планы на будущее. Произошло существенное повышение уровня политического диалога между странами, подтвердилась близость или совпадение позиций по большинству вопросов внутри региональной и международной повестки дня.

Проведенная 29 ноября 2019 года в Ташкенте вторая консультативная встреча глав государств Центральной Азии стала поистине прорывом в региональной дипломатии. Результаты саммита и дальнейший ход развития событий показал, что диалог перерос в новый формат. Сегодня регион быстро превращается во взаимосвязанную арену, а устранение препятствий, мешавших прежде потоку товаров, услуг и капитала, становится все более актуальным. В новой региональной дипломатии появились устойчивые тенденции.

В ходе встречи стороны подчеркнули, что не намерены создавать новую международную организацию, а также направлять свои действия против интересов других стран. Участники саммита отметили, что государства региона готовы к продолжению открытого экономического сотрудничества с партнерами, международными и региональными организациями. Президент Шавкат Мирзиёев заявил о стремлении создания «безбарьерной» Центральной Азии, имея в виду снятие препятствий на границах, оформление пунктов пропуска, что не будет мешать свободному перемещению людей и грузов.

В региональной дипломатии Узбекистан рассматривает перспективы стабильного и устойчивого развития Центральной Азии в неразрывной связи с достижением мира в соседнем Афганистане и его восстановлением. Исходя из этого Ташкент прилагает активные усилия для расширения сотрудничества посредством реализации ряда важных региональных проектов. Выступая 19 сентября 2017 года на 72-й сессии Генеральной Ассамблеи Организации Объединенных Наций, лидер нашей страны заявил, что Узбекистан вносит и далее будет вносить посильный вклад в экономическое восстановление Афганистана, развитие его транспортной и энергетической инфраструктуры, подготовку национальных кадров.

Значимость Афганистана во внешней политике республики была подчеркнута и на международной конференции под эгидой ООН в Самарканде в ноябре 2017-го.

В декабре того же года состоялся первый за 16 лет визит Президента Афганистана Ашрафа Гани в Узбекистан. В результате встречи между странами заключено 20 двусторонних соглашений. В ходе переговоров также решено создать совместную комиссию по вопросам региональной безопасности. Основной акцент сделан на развитии торгово-экономических связей.

Помимо масштабного расширения сотрудничества в сфере торговли, Узбекистан рассматривает реализацию ряда транспортнокоммуникационных проектов. Так, строительство новых дорог может быть использовано для поставок афганских товаров из северных провинций Афганистана в Китай. Наряду с этим планируется строительство новой линии электропередачи Сурхан - Пули-Хумри, которая позволит подключить Афганистан к единому энергетическому кольцу Центральной Азии. А в июле 2018 года в Мазари-Шарифе был открыт узбекско-афганский торговый дом.

Проведение Ташкентской конференции по Афганистану имеет высокую практическую значимость по разрешению афганского кризиса. Сегодня особое значение получило сближение общих подходов и позиций стран Центральной Азии по урегулированию кризиса, вовлечение Афганистана в региональное сотрудничество. Так, Президент Шавкат Мирзиёев инициировал проведение в Ташкенте международной конференции «Мирный процесс, сотрудничество в сфере безопасности и региональное взаимодействие» (26-27 марта 2018 года). Инициатива проведения события столь высокого уровня по Афганистану в Ташкенте является логическим продолжением выверенного и конструктивного внешнеполитического курса Президента Узбекистана по выстраиванию добрососедских отношений со странами ЦА и обеспечению мира, стабильности, безопасности и устойчивого развития в регионе и Афганистане.

На конференции лидер республики заявил: «Нам необходимо начать рассматривать Афганистан не в качестве страны, с территории которой исходит угроза миру и стабильности. Афганистан - наш дружественный партнер и сосед». Эта позиция была полностью поддержана афганским правительством.

Ташкентская конференция по мирному урегулированию в Афганистане руководствуется двумя фундаментальными концепциями. Вопервых, это принцип неделимости безопасности, а именно отказ от разделения угроз безопасности на «наши и чужие». Во-вторых, региональная стабильность в конечном счете будет зависеть от успешной интеграции Афганистана в более широкую систему торговых, экономических и инфраструктурных связей с соседними государствами.

7-8 июля 2020 года в Дохе прошли первые внутриафганские переговоры по вопросам мирного урегулирования между представителями общественно-политических кругов Афганистана и движения «Талибан». Как было отмечено в заявлении МИД Республики Узбекистан, приверженность сторон к достижению устойчивого мира путем инклюзивных межафганских 
переговоров является единственным верным способом урегулирования афганской проблемы.

Таким образом, региональная дипломатия стала новым обликом Узбекистана. Здесь важно умело уловить все тенденции внешнеполитической повестки и учесть национальные интересы. Понимая необходимость, сложность и перспективность этого начинания, наш Президент стал выстраивать совершенно иной региональный диалог с соседями, который привел к появлению новой региональной дипломатии. Сегодняшние результаты и ход развития событий показывают, что эти процессы получили необратимый и предсказуемый характер, и они будут определять будущее не только Узбекистана, но и всего Центральноазиатского региона, включая Афганистан.

Главной тенденцией стала резкая активизация двусторонних и многосторонних отношений во всех направлениях, включая проведение регулярных встреч глав государств, продолжающийся рост товарооборота и инвестиционного сотрудничества, взаимодействие в сфере транспорта, открытые новые транспортные маршруты между Узбекистаном и государствами региона. Растут культурный обмен и гуманитарные связи. Совершенно неожиданным, но пользующимся успехом стало продвижение конструктивного решения пограничных споров. Позитивная динамика наметилась в урегулировании водных и экологических проблем. Все это свидетельствует о толерантности и перспективности новой региональной дипломатии нашей страны, имеющей значение не только в региональном, но и мировом масштабе.

Такие инициативы создали предпосылки и условия для новой диалоговой площадки в целях консолидированного выражения и конструктивного решения региональных проблем без упреков, конфронтационных настроений и взаимной отчужденности. Нужно отметить, что эта региональная площадка на самом деле имеет важное стратегическое значение, так как в современных международных отношениях наблюдается усиление позиций Азии в условиях жесткой конкуренции с Западом. В таких условиях единая Центральная Азия является связующим звеном между ними. Поэтому необходимо выработать согласованные приоритеты и эффективные механизмы многостороннего партнерства в ключевых сферах.

Новая региональная дипломатия Узбекистана позволила комплексно обсуждать перспективные направления дальнейшего развития сотрудничества в политических, экономических, социально-гуманитарных сферах. Характерной особенностью проводимой политики стала открытость региона к внешнему миру, готовность к сотрудничеству и диверсификации связей с другими странами, международными и региональными организациями.

В Центральной Азии начали набирать силу принципиально новые тенденции регионального развития, заметно повысился уровень политического доверия, что позволило существенно активизировать связи между странами в торгово-экономической сфере. В то же время важно учитывать, что перспективы стабильного и устойчивого развития в регионе неразрывно связаны с достижением мира в соседнем Афганистане, так как обеспечение процветания стран региона невозможно без решения афганского кризиса.

\section{ИСТОЧНИКИ}

1.0 стратегии действий по дальнейшему развитию Республики Узбекистан Указ Президента Республики Узбекистан (Собрание законодательства Республики Узбекистан, 2017г., № $\quad 6, \quad$ ст. 70$) \quad 7$ февраля 2017./ https://mfa.uz/ru/press/news/2017/07/11752/

2.Выступление Президента Республики Узбекистан Шавката Мирзиёева на международной конференции по Афганистану: «Мирный процесс, сотрудничество в сфере безопасности и региональное взаимодействие» 27.03.2018

https://president.uz/ru/lists/view/1601/

3.Заявление Президента

Республики Узбекистан Шавката Мирзиёева на брифинге по итогам Консультативной встречи глав государств Центральной https://president.uz/ru/lists/view/3111

4.Выступление Президента Республики Узбекистан Шавката Мирзиёева на совместном заседании Законодательной палаты и Сената Олий Мажлиса https://president.uz/ru/lists/view/3310

5.Отчет о деятельности Министерства иностранных дел Республики Узбекистан за 2017 год. https://mfa.uz/2017

6.Отчет о деятельности Министерства иностранных дел Республики Узбекистан за 2018 год. https://mfa.uz/2018

7.Спецпредставитель президента Узбекистана по Афганистану - о роли Ташкента, талибах и индийском интересе. http://berleknkp.com/analitics/7266-specpredstavitel-prezidentauzbekistana-po-afganistanu-o-roli-tashkenta-talibah-iindiyskom-interese.html.

8.Materialy mezhdunarodnoy nauchno prakticheskoy konferentsii 15-16 oktyabrya 2019 goda. Voyennyye konflikty sovremennosti: soderzhaniye i izvlchennyye uroki. st.48-49 T.2019. Akademiya vooruzhennykh sil Respubliki Uzbekistan

9.Materialy mezhdunarodnoy nauchno prakticheskoy konferentsii.21-22 iyunya 2019 goda. «Afg'onistan XX va XXI asr chorrahasida: tarixiy," ijtimoiy - iqtisodiy, siyosiy jihatlari va uning Markaziy Osiyo mamalakatlari bilan o'zaro munosobatlari» T.TashGIV, $2019.428 \mathrm{~s}$

10.Первая консультативная встреча глав государств Центральной Азии.16 марта 2018г. https://mfa.uz/ru/press/news/2018/03/14236/

11.Совместное заявление консультативной встречи глав государств Центральной Азии. г. Ташкент, 29 ноября года https://mfa.uz/ru/press/news/2019/11/22149/ 
12.Выстпуление министра иносранных дел Республики Узбекистан А.Камилова на XXI планерном заседании Сената Олий Мажлиса (г.Ташкент, 24 августа 2019г.) https://mfa.uz/ru/about/speech/2020/03/23749/

13.Тезисы К выступлению зам.министра иностранных дел Республики Узбекистан И.неъматова на втором планерном заседании Сената Олий Мажлиса (28 февраля 2020г., г.Ташкент) https://mfa.uz/ru/about/speech/2020/02/23570/

14.Э. Арипов. Путь к миру в Афганистане: основные этапы и перспективы 27/Май/2020 https://dunyo.info/ru/site/inner/puty_k_miru_v_afgani stane_osnovnie_etapi_i_perspektivi-jGt
14.Д.Курбанов, Региональная политика Узбекистана: приоритеты и достижения. 23.01.2020 http://jashonnews.uz/ru/

15.А.Кадыров. Ключевые приоритеты внешней политики обновленного Узбекистана /Июль/2020 https://dunyo.info/ru/site/inner/klyuchevi e_prioriteti_vneshney_politiki_obnovlennogo_uzbekis tana-y3b.

М.Узаков, Новая многосторонняя дипломатия Узбекистана: сотрудничество во благо мира и стабильности 09/Март/2020 https://dunyo.info/ru/site/inner/novaya_mnogostoronn yaya_diplomatiya_uzbekistana_sotrudnichestvo_vo_b lago_mira_i_stabilynosti-8SG

С.Жураев. Феномен региональной дипломатии Узбекистана //Правда Востока .14 апреля. 2020 года. №76.

\section{FEATURES OF MIGRATION POLICY IN THE RUSSIAN FEDERATION}

\author{
Andreeva Alisa Alekseevna \\ Student of Saint Petersburg state University, \\ Saint Petersburg \\ Ezhova Viktoriia Sergeevna \\ Student of Saint Petersburg state University, \\ Saint Petersburg \\ Koziy Maria Andreevna \\ Student of Saint Petersburg state University, \\ Saint Petersburg
}

Андреева Алиса Алексеевна Студент Санкт-Петербургского государственного университета, 2. Санкт-Петербург

Ежова Виктория Сергеевна Студент Санкт-Петербургского государственного университета, 2. Санкт-Петербург Козий Мария Андреевна

Студент

Санкт-Петербургского государственного университета, г. Санкт-Петербург

\section{АННОТАЦИЯ}

Миграционные процессы оказывают влияние на множество социально-экономических аспектов. Миграция - это сложное явление, которое требует детального изучения в зависимости от целей и задач исследователя. В данной статье рассматриваются статистические данные Росстата о миграционных потоках, а также общая характеристика: сведения о мигрантах, прибывающих в Россию, миграционная политика, причины миграционного перемещения из России в другие страны. Адаптация и интеграция мигрантов в Концепции государственной миграционной политики: характеристика основных направлений правового регулирования. Также описана Концепция, разработанная на 2019-2020 гг., которая будет учитывать множество характеристик мигрантов, в том числе возраст, профессиональные качества, культурные, национальные и другие характеристики. Помимо вышесказанного рассматриваются возможные действия для улучшения процесса интеграции мигрантов. Даются рекомендации, которые поспособствуют прохождению успешной адаптации мигрантов.

\section{ABSTRACT}

Migration processes affect many socio-economic aspects. Migration is a complex phenomenon that requires a detailed study depending on the goals and objectives of the researcher. This article discusses the statistics of Rosstat on migration flows, as well as a general description: information about migrants arriving in Russia, migration policy, reasons for migration from Russia to other countries. Adaptation and integration of migrants in the Concept of state migration policy: characteristics of the main areas of legal regulation. Also described is a Concept developed for 2019-2020 that will take into account many characteristics of migrants, including age, professional qualities, cultural, national, and other characteristics. In addition to the above, possible actions to 